\title{
Hundreds of rice bodies in the subacromial-subdeltoid bursa: report of two cases and literature review
}

\author{
Jiong Jiong Guo ${ }^{*}$, Kailun $\mathrm{Wu}^{2}$, Yingjie $\mathrm{Xu}^{1,2}$ and Huilin Yang ${ }^{1}$
}

\begin{abstract}
Background: Multiple rice bodies (RB) in the shoulder joint is a rare disorder of unknown etiology that requires percutaneous drainage or surgical operation.

Case presentation: We reported arthroscopic removal of hundreds of RB in the subacromial-subdeltoid bursa in two cases by our "chopsticks technique". One was associated with seropositive rheumatoid arthritis and the other was a rare synovial origin possibly due to microinfarction and ischemia after the radiotherapy. Radical debridement of necrotic tissue, "red tissue" and synovitis by arthroscopic radiofrequency ablation was essential for eliminating the cause of RB. A favorable clinical evolution was observed for both patients.

Conclusions: We highlight the importance of patient-specific differential diagnosis and the clinical course of RB to help us further understand the pathogenesis of this uncommon disorder. Meanwhile, evacuation of RB and "red tissue" ablation by arthroscopy showed good results.
\end{abstract}

Keywords: Shoulder, Subacromial-subdeltoid bursa, Rice bodies, Arthroscopy, Chopsticks technique

\section{Background}

Rice bodies (RB) were initially reported as intra-articular proteinaceous masses associated with tuberculosis infection [1]. After that there were sparse reports of RB, rice body formation is associated with infectious arthritis (tuberculosis, atypical mycobacterial infection), rheumatoid arthritis, traumatic arthritis, seronegative arthritis, juvenile arthritis, osteoarthritis and chronic bursitis [2-4]. However, where most reports attentions have been placed on investigating the etiology, radiological appearances and different rare sites, little has been performed on the quantity, clinical course and treatment details of $\mathrm{RB}[2,3,5]$. We present two cases of arthroscopic removal of hundreds of RB in the subacromial-subdeltoid bursa by chopsticks technique with more than a two-year follow-up. We

\footnotetext{
* Correspondence: guojiongjiong@suda.edu.cn; drjjguo@163.com 'Department of Orthopedics, The First Affiliated Hospital of Soochow University, 188 Shizi St, Suzhou 215006, China

Full list of author information is available at the end of the article
}

also counted the definite number of bodies. These results add to our current knowledge about RB in the shoulder.

\section{Case presentation \\ Case 1}

A 27-year-old woman presented with the complaint of a painless mass in her right shoulder that had been growing over the last 4 months. She had a history of rheumatoid arthritis for 5 years. Physical examination revealed a cystic swelling over the anterior aspect of the right shoulder with fusiform shape. Her preoperative active range of flexion was $160^{\circ}$, abduction was $100^{\circ}$, external rotation with the elbow at the side was $70^{\circ}$, and her hand could be placed on the back to the level of the 12th thoracic vertebra. Erythrocyte sedimentation rate $(41 \mathrm{~mm} / \mathrm{hr})$ and C-reactive protein levels $(6.36 \mathrm{mg} / \mathrm{dL})$ were elevated. Evaluation for rheumatoid arthritis revealed an elevation in antibodies to cyclic citrullinated peptides $(80.45 \mathrm{RU} / \mathrm{mL})$. Magnetic resonance imaging (MRI) suggested a markedly distended

(c) The Author(s). 2020 Open Access This article is licensed under a Creative Commons Attribution 4.0 International License, which permits use, sharing, adaptation, distribution and reproduction in any medium or format, as long as you give appropriate credit to the original author(s) and the source, provide a link to the Creative Commons licence, and indicate if changes were made. The images or other third party material in this article are included in the article's Creative Commons licence, unless indicated otherwise in a credit line to the material. If material is not included in the article's Creative Commons licence and your intended use is not permitted by statutory regulation or exceeds the permitted use, you will need to obtain permission directly from the copyright holder. To view a copy of this licence, visit http://creativecommons.org/licenses/by/4.0/ The Creative Commons Public Domain Dedication waiver (http://creativecommons.org/publicdomain/zero/1.0/) applies to the data made available in this article, unless otherwise stated in a credit line to the data. 
subacromial/subdeltoid bursa, which was full of multiple nodules varing in size. These nudules were isointense on $\mathrm{T} 1$ and T2 weighted spin-echo sequences. The rotator cuff was intact and the glenohumeral joint appeared no articular cartilage injury or wear.

Arthroscopic shoulder surgery was performed after careful preparation. The patient was placed in the beach-chair position with the arm forward flexed with $3 \mathrm{~kg}$ of skin traction applied, secured his neck and body, and the back of the chair was at an angle of approximately 60 degrees to the floor [6]. Before the shoulder is placed in traction, and before it is wrapped by a compression self-adhering elastic bandage, it is important to adequately pad the hand and forearm with gauze or foam in order to avoid injuries to the skin from traction and to avoid excessive nerve compression about the forearm and wrist. The setup optimizes arthroscopic visualization by distracting the humerus from the acromion so that the potential space is maximized. The standard posterior "soft spot" portal was used to visualize the subacromial space. Intraoperatively, hundreds of grainlike loose bodies were found to fill the subacromial and subdeltoid bursae. The bodies were picked up with straight forceps and removed one by one. The inflamed bursa and other tissues were ablated by Coblator (ArthoCare Corporation, Sunnyvale, CA). We defined these tissues as "red tissue" because of red color under the scope. Five hundred twenty-five bodies were collected finally ranging in size from $2.5 \mathrm{~mm}$ to $18 \mathrm{~mm}$. (Fig. 1a) The pathological findings demonstrated chronic active inflammation with fibrin deposition and necrosis formation, but no granulomas. RB was mainly composed of fibrous tissue wrapping necrosis and a mass of chronic inflammatory cells with a prominent granulomatous response. Histochemical staining for acid fast bacilli was negative. (Fig. 1b) The patient recovered uneventfully at a two-year follow-up. This was in accord with a diagnosis of rheumatoid-arthritis-associated subacromialsubdeltoid bursitis with rice body formation.

\section{Case 2}

A 45-year-old woman, with a diagnosis of breast cancer, was referred by her oncologist for an orthopaedic review of her left shoulder swelling for 5 months. She received mastectomy 6 years ago and radiotherapy after that. She had no medical history of rheumatoid arthritis, tuberculosis or previous allergies. Her active range of motion was restricted. External rotation with the elbow at the side was $50^{\circ}$. Forward elevation was $130^{\circ}$ and abduction was $80^{\circ}$. Erythrocyte sedimentation rate and C-reactive protein levels were normal. Antibodies to cyclic citrullinated peptides was $14.34 \mathrm{RU} / \mathrm{mL}$, a little high than

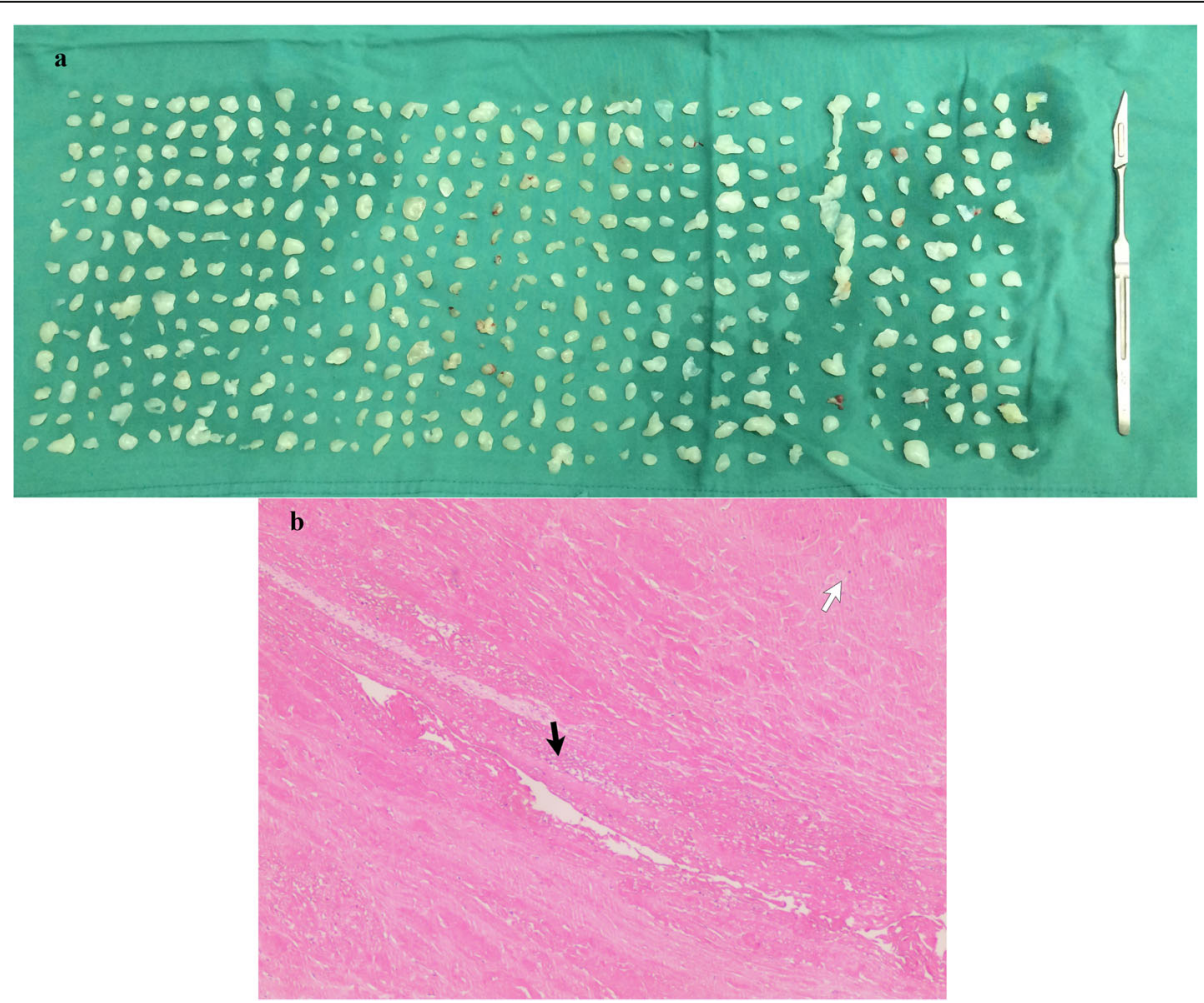

Fig. 1 Gross and pathological photograph in Case 1. a Gross photograph showed 525 spherical rice bodies with the range of 2.5-18 mm in diameter. $\mathbf{b}$ Rice bodies was composed of a collagenous core with chronic inflammatory cells and necrosis (white arrow) surrounded by fibrin layer (black arrow) $(H \& E, \times 100)$ 
normal (0.00-5.00 RU/mL). RF was positive. MRI of the left shoulder showed numerous tiny nodules in the subacromial and subdeltoid bursa, which were surrounded by a moderate degree of bursa fluid. The particles were isointense on both T1- and T2- weighted images, without enhancement after intravenous Gadolinium. (Fig. 2a, b) Rheumatologist did not give her any medication for rheumatologic condition and thought more about the radiotherapy.

Arthroscopic surgery was performed under the beachchair position. Three hundred thirteen grain-like nodules filled the subacromial and subdeltoid bursa. (Fig. 2c, d) All the rice body masses were removed by "chopsticks" technique with straight forceps. Because RB characteristics are soft and smooth, straight forcep is the ideal instrument to pick up them. "Red tissue" was ablated by Coblator as much as possible. She had improved at 3 months followup review with an increases in abduction of $40^{\circ}\left(80^{\circ}\right.$ to $\left.120^{\circ}\right)$, an increase of $10^{\circ}\left(50^{\circ}\right.$ to $\left.60^{\circ}\right)$ in external rotation with the elbow at the side, and by three vertebrae in the height at which they could place their hand on their back. The patient received no medication subsequently and there was no recurrence after 2 years.

\section{Literature review process and results}

An English literature search was conducted on PubMed, MEDLINE and EMBASE covering the span from 2004 to 2015. Search items included rice body, shoulder, arthroscopy, treatments. Articles without treatment and outcome were excluded. We focused on reviewing studies of symptom, surgical procedures, pathogenesis and outcomes.

After screening of all abstracts, four articles were included. One study reported two elderly cases with shorttime recurrence after synovectomy and removal of rice bodies [7]. Furthermore, there were two rare cases. One was an infantile case with polyarticular $R B$, the other was a rice body formation associated with bioabsorbable suture anchor after arthroscopic repair $[8,9]$. Subramaniam et al. reported the treatment of giant RB caused by

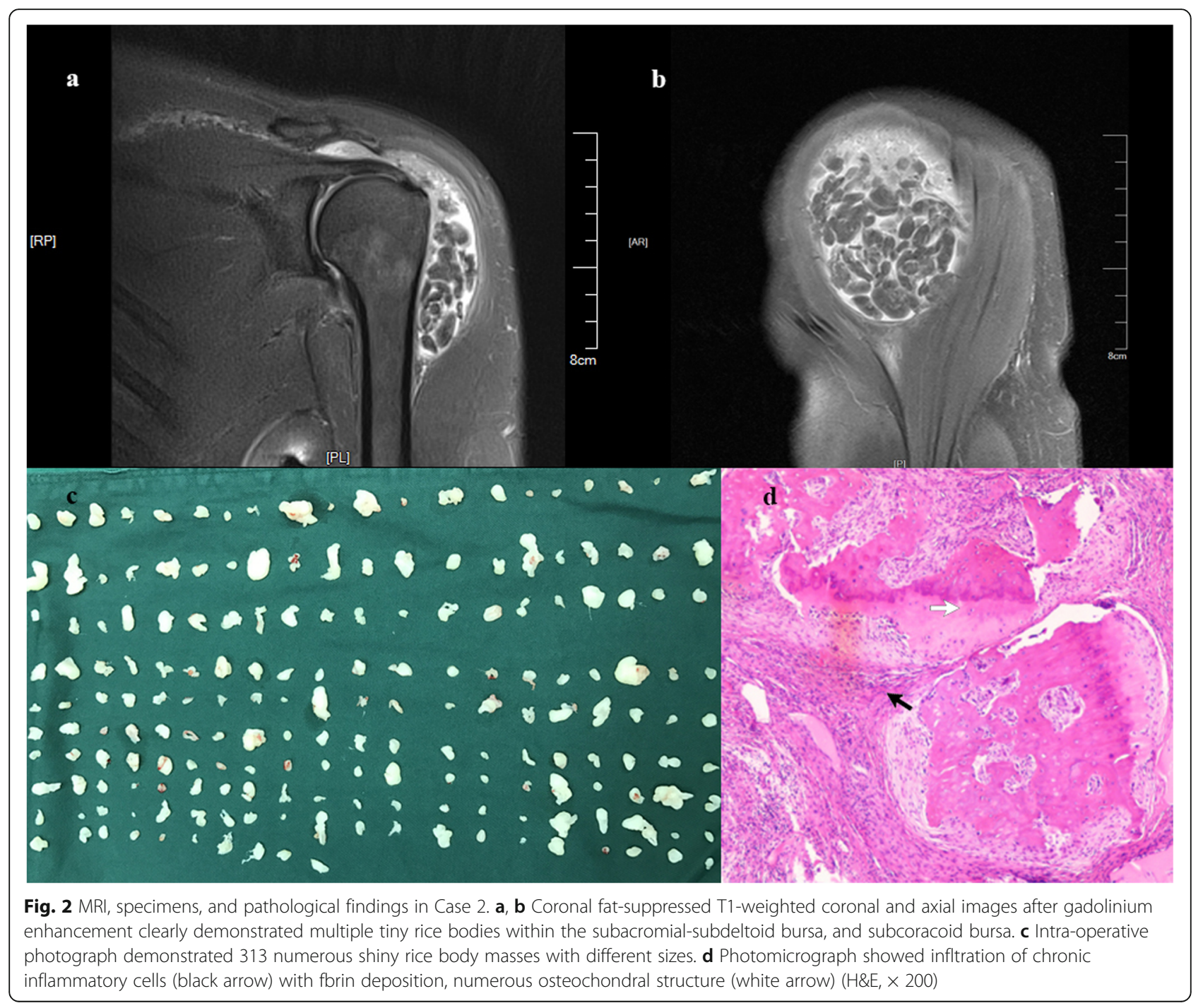


rheumatoid arthritis [4]. In our series, we described chopsticks technique to remove pathogenic factor, which achieved favorable effects. The results of these reports were summarized in Table 1.

\section{Discussion and conclusions}

We presented two cases of $R B$ in the shoulder with arthroscopic debridement and evacuation of all loose bodies. Careful arthroscopic exploration of the subacromial, subdeltoid and subcoracoid bursae to reveal all bodies was a hard job. The proliferative nature of the inflamed synovium can obscure the arthroscopic view. Loose bodies of synovial origin and eburnation of articular cartilage to bone (especially of the humeral head) were noted during the shoulder arthroscopic procedure. Consequently, we could not count the definite number of bodies by arthroscopic drainage. Generally, many surgeons used the shaver to remove and put these multiple loose bodies into the tray. But crushing of bodies because of shaver was common. In order to add our knowledge of $\mathrm{RB}$, we removed and counted the definite numbers of bodies in the subacromial and subdeltoid bursa. Beach-chair position with the arm held in flexion optimizes arthroscopic visualization by distracting the humerus from the acromion [6]. Although requiring arthroscopic skills and patience, our technique seems to be safe and reproducible, and it provides significant functional improvements in the patients with RB, also with aesthetic benefits in young female patients.

The cause of rice body formation remains obscure, but is most likely an unusual complication of chronic bursitis. However, seldom was there any underlying pathology reported. The first case in the study was associated with seropositive rheumatoid arthritis. Some investigators have suggested microinfarctions after intra-articular synovial inflammation and ischaemia, with subsequent synovial shedding and encasement by fibrin derived from synovial fluid as a possible cause $[10,11]$. Based on the results of previous studies in vivo of local temporary ischemia on the effectiveness of ionizing radiation-based anti-cancer therapy, we thought an alteration of the synovial fluid after radiotherapy is also a possible mechanism of the second case. A severe inflammatory bursitis with $\mathrm{RB}$ formation related to the poly-L-lactic acid anchor was reported [9]. Clinical characteristics, radiologic and laboratory findings of RB have been reported. To our knowledge, the definite numbers and best treatment of RB have not been reported. Calabozo et al. reported arthroscopic drainage with intra-articular urokinase for synovial effusions with rice bodies [12]. Ergun et al. mentioned open surgical intervention of RB in the thickened common flexor tendon sheath of the wrist [13]. Lui reported a patient with idiopathic tenosynovitis and RB formation at the anterior ankle [5]. It was treated with tendoscopic synovectomy and was complicated by pseudoaneurysm of the dorsalis pedis artery.

RB formation is usually associated with bursitis, inflamed synovial shedding, or other rheumatoid soft tissue changes. Another advantage of arthroscopy is Coblator, which can ablate those inflamed tissue easily and completely. Radical debridement of the inflamed bursa and its contents was important for the prognosis. There was neither communication with the underlying glenohumeral joint nor obvious compromise of the rotator cuff. These "red tissues" are different from pannus, which is a sheet of

Table 1 Selected literature review of rice bodies in shoulder for comparison of outcomes reported

\begin{tabular}{|c|c|c|c|c|c|c|c|}
\hline $\begin{array}{l}\text { Authors/ } \\
\text { Published Year }\end{array}$ & $\begin{array}{l}\text { Age/ } \\
\text { sex }\end{array}$ & Location & Symptom & Procedures & Pathogenesis & $\begin{array}{l}\text { Follow- } \\
\text { up time }\end{array}$ & Outcome \\
\hline \multirow[t]{2}{*}{$\begin{array}{l}\text { Tan et al./ } 2004 \\
{[7]}\end{array}$} & $70 / \mathrm{M}$ & $\begin{array}{l}\text { Right } \\
\text { shoulder }\end{array}$ & S, full ROM & $\begin{array}{l}\text { Synovectomy arthroscopic } \\
\text { drainage and removal of rice } \\
\text { bodies }\end{array}$ & $\begin{array}{l}\text { Chronic synovitis and } \\
\text { synovial chondromatosis }\end{array}$ & 6 & $\begin{array}{l}\text { Recurrence and } \\
\text { Re-operation }\end{array}$ \\
\hline & $88 / F$ & $\begin{array}{l}\text { Left } \\
\text { shoulder }\end{array}$ & $\begin{array}{l}\text { S, P and } \\
\text { decreased } \\
\text { ROM }\end{array}$ & Ditto & $\begin{array}{l}\text { Arthritis and synovial } \\
\text { chondromatosis }\end{array}$ & $\begin{array}{l}4 \\
\text { months }\end{array}$ & $\begin{array}{l}\text { Recurrence, pain } \\
\text { but good ROM }\end{array}$ \\
\hline $\begin{array}{l}\text { Mutlu et al./ } \\
2004[8]\end{array}$ & $4 / F$ & $\begin{array}{l}\text { Left } \\
\text { shoulder } \\
\text { and knee }\end{array}$ & $\begin{array}{l}\text { S, decreased } \\
\text { ROM }\end{array}$ & $\begin{array}{l}\text { Removal of rice bodies but not } \\
\text { synovium }\end{array}$ & Unknown & 1-year & No recurrence \\
\hline $\begin{array}{l}\text { Subramaniam } \\
\text { et al./2012 [4] }\end{array}$ & $49 / F$ & $\begin{array}{l}\text { Right } \\
\text { shoulder }\end{array}$ & $\begin{array}{l}\text { S, P and } \\
\text { decreased } \\
\text { ROM }\end{array}$ & $\begin{array}{l}\text { Removal of giant rice bodies, } \\
\text { subacromial and subdeltoid } \\
\text { bursitis }\end{array}$ & Rheumatoid Arthritis & $\begin{array}{l}30 \\
\text { months }\end{array}$ & No recurrence \\
\hline $\begin{array}{l}\text { Sivaloganathan } \\
\text { et al. /2015 [9] }\end{array}$ & $60 / M$ & $\begin{array}{l}\text { Left } \\
\text { shoulder }\end{array}$ & $\begin{array}{l}\text { S, P and } \\
\text { decreased } \\
\text { ROM }\end{array}$ & $\begin{array}{l}\text { Debridement, removal of rice } \\
\text { bodies, anchor and suture removal. }\end{array}$ & $\begin{array}{l}\text { Post-operation of shoulder } \\
\text { (poly-L-lactic acid anchor) }\end{array}$ & 2-year & No recurrence \\
\hline \multirow[t]{2}{*}{$\begin{array}{l}\text { Guo et al. } \\
\text { (current study) }\end{array}$} & $27 / F$ & $\begin{array}{l}\text { Right } \\
\text { shoulder }\end{array}$ & S, full ROM & $\begin{array}{l}\text { Chopsticks technique and removal } \\
\text { of "red tissue" }\end{array}$ & Rheumatoid arthritis & 2-year & No recurrence \\
\hline & $45 / F$ & $\begin{array}{l}\text { Left } \\
\text { shoulder }\end{array}$ & $\begin{array}{l}\text { S, decreased } \\
\text { ROM }\end{array}$ & Ditto & Radiotherapy & 2-year & No recurrence \\
\hline
\end{tabular}


inflammatory granulation tissue that spreads from the synovial membrane and invades the glenohumeral joint in rheumatoid arthritis. Our findings were consistent with previous reports noting that necrotic tissue, "red tissue" or synovitis played a vital role in the development of the formation of rice body [4, 7-9].

In conclusion, we describe two cases of RB in female patients, one had rheumatoid arthritis and the other had a history of breast cancer. Beach-chair positioned shoulder arthroscopy was performed combined with bodies removal, counting, and debridement of inflamed soft tissue. We highlight the significance of arthroscopic chopsticks technique and debridement of "red tissue" response to inflammation as much by ablation. Further studies are necessary to better understand the relation among the surgical, radiological findings and prognosis.

\section{Supplementary information}

Supplementary information accompanies this paper at https://doi.org/10. 1186/s12891-020-03563-0.

Additional file 1

\section{Abbreviations}

RB: Rice bodies; CA: Coblator; MRI: Magnetic resonance imaging

\section{Acknowledgements}

The authors wish to thank Dr. Ralph Gambardella, Kerlan-Jobe Orthopaedic Clinic Los Angeles, California, USA, for his assistance with this study.

\section{Authors' contributions}

JJG and KW designed the study and drafted the manuscript. YX and HY helped to draft the manuscript and prepare the figures. JJG and $Y X$ performed the surgery. All authors have read and approved the final manuscript.

\section{Funding}

Not applicable.

Availability of data and materials

All data concerning the case are presented in the manuscript.

Ethics approval and consent to participate

Not applicable.

\section{Consent for publication}

Written informed consents were obtained from the patients for publication of this case report, along with any accompanying images. A copy of the written consent is available for review by the Editor of this journal.

\section{Competing interests}

The authors declare that they have no competing interests.

\section{Author details}

${ }^{1}$ Department of Orthopedics, The First Affiliated Hospital of Soochow University, 188 Shizi St, Suzhou 215006, China. ${ }^{2}$ Department of Orthopedics, Suzhou Dushuhu Public Hospital (The Affiliated Dushuhu Hospital of Soochow University), Suzhou, China.
Received: 19 November 2019 Accepted: 3 August 2020

Published online: 12 August 2020

\section{References}

1. Reise H. Die Reiskorpschen in tuberculs erkranken synovalsacken [in German]. Dtsch Z Chir. 1895:42:1.

2. Forse $\mathrm{CL}$, Mucha BL, Santos MLZ, Ongcapin EH. Rice body formation without rheumatic disease or tuberculosis infection: a case report and literature review. Clin Rheumatol. 2012;31(12):1753-6. https://doi.org/10. 1007/s10067-012-2063-8.

3. Griffith JF, Peh WCG, Evans NS, Smallman LA, Wong RW, Thomas AM Multiple rice body formation in chronic subacromial/subdeltoid bursitis: MR appearances. Clin Radio. 1996;51(7):511-4.

4. Subramaniam R, Tan JWL, Chau CYP, Lee KT. Subacromial bursitis with giant rice bodies as initial presentation of rheumatoid arthritis. J Clin Rheumatol. 2012;18(7):352-5. https://doi.org/10.1097/RHU.0b013e3182677023.

5. Lui TH. Dorsalis pedis psuedoaneurysm: a complication followed extensor tendoscopy of the ankle in a non-tuberculosis patient with tenosynovitis with rice body formation. Foot Ankle Surg. 2016;22:e1-5. https://doi.org/10. 1016/j.fas.2015.12.003.

6. Lafosse L, Tomasi A, Corbett S, Baier G, Willems K, Gobezie R. Arthroscopic release of suprascapular nerve entrapment at the suprascapular notch: technique and preliminary results. Arthroscopy. 2007;23(1):34-42. https://doi. org/10.1016/j.arthro.2006.10.003.

7. Tan CHA, Rai SB, Chandy J. MRI appearances of multiple rice body formation in chronic subacromial and subdeltoid bursitis, in association with synovial chondromatosis. J Clin Radiol. 2004;59(8):753-7. https://doi. org/10.1016/j.crad.2004.03.012.

8. Mutlu H, Silit E, Pekkafali Z, Karaman B, Omeroglu A, Basekim CC. Multiple rice body formation in the subacromial-subdeltoid bursa and knee joint. $J$ Skeletal Radiol. 2004;33(9):531-3. https://doi.org/10.1016/S00099260(96)80193-0.

9. Sivaloganathan S, Amr R, Shrivastava R, Relwani J. The risotto sign - a severe inflammatory bursitis with rice body formation, complicating a rotator cuff repair with a bioabsorbable suture anchor. J Royal Soc Med Open. 2015;6(1):1-3. https://doi.org/10.1177/2054270414562986.

10. Cheung HS, Ryan LM, Kozin F, McCarty DJ. Synovial origins of Rice bodies in joint fluid. Arthritis Rheum. 1980;23:72-6. https://doi.org/10.1002/art.1780230112.

11. Walichiewicz P, Sochanik A, Przybyszewski WM. Influence of local temporary ischemia on radiotherapy effects. J Cancer Ther. 2011;2:209-16.

12. Calabozo M, Aretxabalal A-RA, et al. Intra-articular urokinase: a new drainage technique for synovial effusions with rice bodies. J Rheumatol. 1998:25:394-5.

13. Ergun $\mathrm{T}$, Lakadamyali $\mathrm{H}$, Aydin $\mathrm{O}$, et al. Multiple rice body formation accompanying the chronic nonspecific tenosynovitis of flexor tendons of the wrist. Radiat Med. 2008;26:545-8. https://doi.org/10.1007/s1 1604-008-0270-7.

\section{Publisher's Note}

Springer Nature remains neutral with regard to jurisdictional claims in published maps and institutional affiliations.
Ready to submit your research? Choose BMC and benefit from:
- fast, convenient online submission
- thorough peer review by experienced researchers in your field
- rapid publication on acceptance
- support for research data, including large and complex data types
- gold Open Access which fosters wider collaboration and increased citations
- maximum visibility for your research: over $100 \mathrm{M}$ website views per year
At BMC, research is always in progress.
Learn more biomedcentral.com/submissions 